\title{
ANALISIS PENGARUH KEBISINGAN TERHADAP KELELAHAN KARYAWAN DI BAGIAN OPERASI-1 PT. PUPUK ISKANDAR MUDA, KRUENG GEUKUH, ACEH UTARA
}

\author{
Amri, Cut Ita Erliana, Rizki Aidil Fairuza Lubis \\ Jurusan Teknik Industri, Fakultas Teknik, Universitas Malikussaleh, Lhokseumawe, Aceh-Indonesia \\ Corresponding Author: amri_ir@yahoo.co.id
}

\begin{abstract}
Abstrak - Bagian Operasi-1 adalah salah satu pusat produksi dan mengghasilkan bunyi yang sangat bising pada PT.Pupuk Iskandar Muda khususnya di kawasan Compressor House Urea-1. Lingkungan kerja yang tidak memenuhi syarat seperti kebisingan melebihi ambang batas dapat menimbulkan gangguan kesehatan. Permasalahan dalam penelitian melihat pengaruh kebisingan terhadap kelelahan Pada karyawan di bagian operasi-1 khususnya di kawasan Compressor House Urea. Metode penelitian yang digunakan adalah melakukan perhitungan tingkat kebisingan. Penyebaran kuisioner kepada karyawan di dibagian operasi-1 khususnya dikawasan Compressor House Urea-1. Penelitian ini bertujuan untuk mengetahui tingkat kebisingan berpengaruh terhadap kelelahan karyawan. Pengukuran tingkat kebisingan dengan menggunakan Sound Level Meter. Sampel yang menjadi objek penelitian adalah semua anggota populasi yang berjumlah 30 orang orang. Pengambilan data dilakukan dengan menggunakan kuesioner untuk mengetahui karakteristik responden,. Teknik pengolahan dan analisis data dilakukan dengan uji statistik menggunakan program komputer SPSS versi 16.0. Hasil analisis dengan menggunakan program komputer SPSS, uji pengaruh kebisingan terhadap kelelahan diketahui bahwa nilai Sig. sebesar 0,693 yang artinya korelasi kuat. hasil uji ini yang dilakukan adanya pengaruh kebisingan yang sangat signifikan terhadap kelelahan karyawan
\end{abstract}

Kata Kunci : Kebisingan, Kelelahan, Regresi, Korelasi,

\section{Pendahuluan}

Kebisingan merupakan salah satu faktor bahaya fisik yang sering dijumpai di lingkungan kerja. Kebisingan tidak dapat dipisahkan dari perkembangan industrilisasi karena hampir semua proses produksi di lingkungan yang berbasis tenaga mesin akan menimbulkan kebisingan. Dalam kehidupan sehari-hari tingkat kebisingan itu memiliki tingkatan yang berbeda-beda, baik dalam lingkungan kerja, lingkungan belajar ataupun lingkungan istirahat, dimana pengaruh kebisingan tersebut dapat menyebabkan beberapa gangguan kesehatan secara berkala, seperti gangguan fisiologis yang dapat menyerang peredaran darah, gangguan tidur, gangguan pada sistem saraf dan otot menjadi tegang, sedangkan gangguan psikologis dapat mengakibatkan cepat marah, jenuh, tidak konsentrasi, tidak nyaman berada di tempat tersebut dan produktivitas kerja menurun. PT. Pupuk Iskandar Muda merupakan salah satu perusahaan yang menggunakan mesin dan menimbulkan kebisingan yang dapat mengganggu kenyamanan karyawan pada saat melakukan aktivitas. PT. Pupuk Iskandar Muda memiliki beberapa area/lokasi kerja, yaitu GE House, Package Boiler, Compressor 
House Urea 1, Centrifuge, Control Room Urea, Comp. House NH, Area Gudang, Cooling Water. Dari bebarapa area/lokasi kerja tersebut berdasarkan hasi pengukuran /pemantauan Departemen Keselamatan Kerja dan Lingkungan Hidup (K3\&LH) ada beberapa lokasi yang melebihi nilai ambang batas yang di persyaratkan yaitu 85 Db 8 jam kerja normal sesuai dengan peraturan kebisingan menteri Tenaga Kerja, Transmigrasi, Koperasi No. SE 01/MEN/1978. Area/lokasi Compressor House Urea-1 yang merupakan salah satu faktor pengganggu kenyamanan karyawan yang melakukan aktivitas pada area tersebut dan karyawan seringkali mengeluh dengan merasa tidak nyaman di akibatkan tingkat kebisinganya sudah mencapai $97 \mathrm{Db}$ dan melebihi ambang batas kebisingan yang sudah di tetapkan pada perusahaan ( $N A B>85)$ dan dengan keadaan kebisingan yang melebihi ambang batas yang telah di tetapkan pasti akan mempengaruhi aktivitas karyawan pada area tersebut, maka dari itu dapat dikatakan tidak memiliki standart peraturan kebisingan menteri Tenaga Kerja, Transmigrasi, Koperasi No. SE 01/MEN/1978. Maka mengingat pentingnya lingkungan kerja yang terhindar dari kebisingan, maka perlu dilakukan penelitian terkait dengan studi kasus ini berdasarkan data yang diteliti di perusahaan ini. Mengingat pentingnya kenyamanan di dalam lingkungan kerja yang terhindar dari kebisingan di area kerja dan kebisingan lingkungan sekitar Compressor House Urea1, maka dengan itu perlu dilakukan penelitian yang berjudul "Analisis Pengaruh Tingkat Kebisingan Terhadap Kelelahan Karyawan di Bagian Operasi-1" PT. Pupuk Iskandar Muda., Krueng Geukuh Aceh Utara".

\section{Landasan Teori}

Copyright (02019 Department of Industrial Engineering. All rights reserved.

\subsection{Pengertian Kebisingan}

Kebisingan merupakan salah satu faktor fisik lingkungan kerja yang dapat menimbulkan dampak pada gangguan pendengaran (audiotory) dan extra audiotory seperti stress kerja atau psikologik, hipertensi, kelelahan kerja dan perasaan tidak senang. Secara umum bising adalah bunyi yang tidak diinginkan[1].

\subsection{Nilai Ambang Batas Kebisingan}

Nilai ambang batas kebisingan adalah 85 dB yang dianggap aman untuk sebagian besar tenaga kerja bila bekerja 8 jam/hari atau $40 \mathrm{jam} / \mathrm{minggu}$. Nilai ambang batas untuk kebisingan di tempat kerja adalah intensitas tertinggi dan merupakan rata-rata yang masih dapat diterima tenaga kerja tanpa mengakibatkan hilangnya daya dengar yang tetap untuk waktu terus-menerus tidak lebih dari dari 8 jam sehari atau 40 jam seminggunya. Nilai ambang batas kebisingan lama kerja yang diizinkan dalam sehari dapat dilihat pada Tabel 1.

\begin{tabular}{clc} 
Tabel.1 NAB dan Lama Kerja \\
\hline $\begin{array}{c}\text { Lama } \\
\text { Pemaparan }\end{array}$ & $\begin{array}{l}\text { Per } \\
\text { Hari }\end{array}$ & $\begin{array}{l}\text { Tingkat } \\
\text { Kebisingan (dB) }\end{array}$ \\
\hline 8 & & 85 \\
3 & & 88 \\
2 & Jam & 91 \\
1 & & 94 \\
30 & & 97 \\
15 & Menit & 100 \\
7,5 & & 103 \\
3,75 & & 106 \\
1,88 & & 109 \\
\hline
\end{tabular}

Sumber : Kep-51/MEN/1999

\subsection{Tingkat Kebisingan}

1. Tingkat Kebisingan Ekuivalen

Pernyataan tingkat kebisingan siang hari merupakan model tingkat kebisingan equivalent yang dipergunakan untuk

Industrial Engineering Journal Vol.8 No.1 (2019) 22-29 
Ergonomic and Work Design

menyatakan tingkat kebisingan pada siang hari. Sesuai ketentuan dari menteri negara lingkungan hidup, data tingkat kebisingan ekuivalen pada setiap titik dan waktu diklasifikasi dalam 2 jenis, yakni tingkat kebisingan siang hari dan malam hari. Interval waktu sesuai peraturan KEP48/MENLH/11/1996 dengan waktu pengukuran dilakukan selama aktifitas 24 jam (LSM) dengan cara pada siang hari tingkat aktifitas yang paling tinggi selama 16 jam (LS) pada selang waktu 06.00-22.00. Tingkat kebisingan yang mewakili waktu siang hari diperoleh dari pengukuran kebisingan selama 14 jam pada pukul 09:00, 11:00, 13:00, 15:00, 17:00 dan 21:00.

Model matematis untuk tingkat kebisingan siang hari disajikan menurut persamaan:

$$
\begin{aligned}
& \text { Leq } \\
& =10 \log \left\{f_{1} 10^{0.1 L_{1}}\right. \\
& \left.+f_{2} 10^{0.1 L_{2}}+\ldots \ldots \ldots f_{n} 10^{0.1 L_{n}}\right\}
\end{aligned}
$$

Keterangan :

$f_{1}=$ fraksi waktu dengan titik pengukuran (yaitu $=1 / n$ )

$L_{n}=$ Tingkat Kebisingan ke- $n(n)$

\section{Tingkat Kebisingan Ekuivalen Total}

Tingkat kebisingan ekuivalen total dimaksudkan untuk mengetahui rata-rata tingkat kebisingan pada setiap titik pengukuran dari rentang waktu pengukuran.

Model matematis untuk tingkat kebisingan siang hari disajikan menurut persamaan:

dengan menggunakan formula:

$$
\begin{aligned}
& \quad \begin{array}{l}
\text { Leq } \\
\quad=10 \log \left\{f_{1} 10^{0.1 L_{1}}\right. \\
\left.\quad+f_{2} 10^{0.1 L_{2}}+\ldots \ldots f_{n} 10^{0.1 L_{n}}\right\}
\end{array} \\
& \mathrm{f}=\text { fraksi waktu dengan pengukuran } \\
& \text { (yaitu }=1 / \mathrm{f} \text { ) } \\
& L_{\mathrm{n}}=\text { Tingkat Kebisingan ke-n }
\end{aligned}
$$$$
\text { (yaitu }=1 / f \text { ) }
$$

\section{Tingkat Kebisingan Siang}

Copyright (C2019 Department of Industrial Engineering. All rights reserved.
Sesuai ketentuan dari menteri negara lingkungan hidup, data tingkat kebisingan ekuivalen pada setiap titik dan waktu diklasifikasi dalam 2 jenis, yakni tingkat kebisingan siang hari dan malam hari. Interval waktu sesuai peraturan KEP48/MENLH/11/1996 dengan waktu pengukuran dilakukan selama aktifitas 24 jam (LSM) dengan cara pada siang hari tingkat aktifitas yang paling tinggi selama 16 jam (LS) pada selang waktu 06.00-22.00. Tingkat kebisingan yang mewakili waktu siang hari diperoleh dari perhitungan tingkat kebisingan ekuivalen.

2.4 Pemetaan dan Kontur (Noise Mapping)
Pemetaan diartikan sebagai
penggambaran secara visual yang menghasilkan sebuah peta, sedangkan pemetaan kebisingan berarti penggambaran secara visual dari tingkat kebisingan yang ditimbulkan pada tiap-tiap titik pengamatan dimana pengukuran ini akan menghasilkan sebuah peta kontur kebisingan. Pengukuran dengan membuat peta kontur sangat bermanfaat dalam mengukur kebisingan, karena peta tersebut dapat menentukan gambar tentang kondisi kebisingan dalam cakupan area.. Biasanya dibuat kode pewarnaan untuk menggambarkan keadaan kebisingan, warna hijau untuk kebisingan dengan intensitas dibawah 84 dBA warna merah untuk tingkat kebisingan yang tinggi diatas 90 dBA, warna kuning untuk kebisingan dengan intensitas antara 85-87 dBA. Pembuatan peta kontur kebisingan pada penelitian ini menggunakan aplikasi Surfer 15. Surfer adalah sebuah aplikasi yang dapat digunakan untuk proses pemetaan (proses membuat peta) berupa peta kontur dan 3D [2].

\subsection{Kelelahan Kerja \\ Lelah bagi setiap orang mempunyai \\ arti tersendiri dan tentu saja subjektif}


Ergonomic and Work Design

sifatnya. Lelah merupakan suatu perasaan. Kelelahan disini adalah aneka keadaan yang disertai penurunan efisiensi dan ketahanan dalam bekerja. Kata lelah menunjukan keadaan yang berbeda-beda, tetapi semuanya berakibat kepada pengurangan kapasitas kerja dan ketahanan tubuh [3].

$$
\text { Kelelahan kerja merupakan }
$$
penurunan efisiensi dan ketahanan tubuh. Kelelahan kerja adalah kelelahan yang terjadi pada manusia oleh karena kerja yang dilakukan. Lelah seperti itu mempunyai arti yang lebih luas dari pada kelelahan otot yang dirasakan sebagai sakit atau nyeri pada otot-otot, kelelahan seperti itu adalah kelelahan yang bersifat umum. Banyak definisi yang diberikan pada kelelahan ini tetapi secara garis besarnya dapat dikatakan bahwa kelelahan ini merupakan suatu pola yang timbul pada suatu keadaan, yang secara umum terjadi pada setiap individu, yang telah tidak sanggup lagi untuk melakukan aktivitasnya [4].

\subsection{Hubungan Kebisingan dengan} Kelelahan Kerja

Ketika tenaga kerja lama terpapar bising, maka tenaga kerja tersebut akan mengalami beberapa gangguan. Adapun gangguan tersebut salah satunya adalah kelelahan. Kelelahan tersebut disebabkan oleh monotoni pekerjaan, intensitas dan lamanya kerja mental dan fisik, keadaan lingkungan. Sebab-sebab mental seperti tanggung jawab, kekhawatiran dan konflik. Jika kelelahan tersebut sudah merupakan keadaan penyakit, maka bersifat medis dengan gejala seperti pusing, sesak nafas, hilang nafsu makan, gangguan pencernaan dan sulit tidur.

Suara yang terlalu bising dan berlangsung lama dapat menimbulkan stimulasi daerah di dekat area penerimaan pendengaran primer yang akan menyebabkan sensasi suara gemuruh dan berdering.

Kelelahan adalah reaksi fungsional dari pusat kesadaran yaitu cortex cerebri yang dipengaruhi oleh dua sistem antagonistik yaitu sistem penghambat (inhibisi) dan sistem penggerak (aktivasi) dimana keduanya berada pada susunan syaraf pusat. Sistem penghambat terdapat dalam thalamus yang mampu menurunkan kemampuan manusia bereaksi dan menyebabkan kecenderungan untuk tidur. Sistem penggerak terdapat dalam formatio retikularis yang dapat merangsang pusat vegetatif untuk konversi ergotropis dari dalam tubuh ke arah bekerja. Maka keadaan seseorang pada suatu saat sangat tergantung pada hasil kerja diantara dua sistem antagonis tersebut. [5].

\subsection{Regresi dan Korelasi Sederhana}

Untuk mencari analisis pengaruh, dapat digunakan pengukuran dan perbandingan statistika regresi dan korelasi sebagai berikut:

\section{Regresi}

Regresi linear adalah alat statistik yang dipergunakan untuk mengetahui pengaruh antara satu atau beberapa variabel terhadap satu buah variabel. Variabel yang mempengaruhi sering disebut variabel bebas, variabel independen atau variabel penjelas. Variabel yang dipengaruhi sering disebut dengan variabel terikat atau variabel dependen. Regresi linear hanya dapat digunakan pada skala interval dan ratio.Secara umum regresi linear terdiri dari dua, yaitu regresi linear sederhana yaitu dengan satu buah variabel bebas dan satu buah variabel terikat dan regresi linear berganda dengan beberapa variabel bebas dan satu buah variabel terikat. Rumus regresi linear sederhana sebagi berikut :

Industrial Engineering Journal Vol.8 No.1 (2019) 22-29 
Ergonomic and Work Design

$$
\mathrm{Y}^{\prime}=\mathrm{a}+\mathrm{bX}
$$

Keterangan:

$Y^{\prime}=$ Variabel dependen (nilai yang diprediksikan)

$X=$ Variabel independen

$a=$ Konstanta (nilai $Y^{\prime}$ apabila $X=0$ )

$b=$ Koefisien regresi (nilaipeningkatan ataupun penurunan)

Nilai-nilai a dan $b$ dapat dihitung dengan menggunakan rumus dibawah ini:

$$
b=\frac{n \sum X Y-\sum X \sum Y}{n \sum X^{2}-\left(\sum X\right)^{2}}
$$

Untuk mencari nilai a dengan menggunakan rumus :

$$
a=\bar{y}-b \bar{x}
$$

Keterangan:

$\mathrm{n}$ = jumlah titik (pasangan pengamatan)

$\bar{x}=$ mean dari variabel $x$

$\bar{y}=$ mean dari variabel $y$

2. Korelasi

Korelasi sederhana merupakan suatu teknik statistik yang dipergunakan untuk mengukur kekuatan hubungan 2 variabel dan juga untuk dapat mengetahui bentuk hubungan antara 2 variabel tersebut dengan hasil yang sifatnya kuantitatif. Kekuatan hubungan antara 2 variabel yang dimaksud disini adalah apakah hubungan tersebut erat, lemah ataupun tidak erat sedangkan bentuk hubungannya adalah apakah bentuk korelasinya linear positif ataupun linear negatif. Koefisien korelasi merupakan indeks atau bilangan yang menyatakan keeratan hubungan antar variabel. Koefisien memiliki nilai antara -1 dan 1. Jika koefisien korelasi bernilai positif, maka variabel-variabel berkorelasi positif. Jika koefisien korelasi bernilai negatif, maka variabel-variabel berkorelasi negatif. Jika koefisien korelasi bernilai 0, maka variabel-variabel tidak memiliki korelasi. Jika nilai korelasi bernilai +1 atau -1, maka variabel-variebel berkorelasi positif atau negatif yang sempurna. korelasi sederhana adalah sebagai berikut:

$$
r=\frac{N \sum X Y-\left(\sum X\right)\left(\sum Y\right)}{\sqrt{\left[N \sum X^{2}-\left(\sum X\right)^{2}\right]\left[N \sum Y^{2}-\left(\sum Y\right)^{2}\right]}}
$$

Keterangan:

$\mathrm{N}$ = Banyaknya pasangan data $\mathrm{X}$ dan $\mathrm{Y}$

$\Sigma X=$ Total jumlah dari variabel $X$

$\Sigma Y=$ Total jumlah dari variabel $Y$

$\Sigma X^{2}=$ Kuadrat dari total jumlah variabel $X$

$\sum Y^{2}=$ Kuadrat dari total jumlah variabel $Y$

$\sum X Y=$ Hasil perkalian dari total jumlah variabel $X$ dan $Y$

Untuk melihat seberapa erat hubungan antar variabel, kita dapat melihatnya dari pedoman derajat hubungan seperti pada Tabel 2 berikut [6].

Tabel 2. Derajat Pedoman Hubungan

\begin{tabular}{ll}
\hline $\begin{array}{c}\text { Nilai Pearson } \\
\text { Correlation }\end{array}$ & Keterangan \\
\hline $0,00 \mathrm{~s} / \mathrm{d} 0,20$ & Tidak ada korelasi \\
$0,21 \mathrm{~s} / \mathrm{d} 0,40$ & Korelasi lemah \\
$0,41 \mathrm{~s} / \mathrm{d} 0,60$ & Korelasi sedang \\
$0,61 \mathrm{~s} / \mathrm{d} 0,80$ & Korelasi kuat \\
$0,81 \mathrm{~s} / \mathrm{d} 1,00$ & Korelasi sempurna \\
\hline
\end{tabular}

Sumber: Harinaldi, 2005

\section{Metode Penelitian}

Adapun teknik pengumpulan data yang yang filakukan dalam penelitian ini adalah : Pengumpulan data dengan cara memberi seperangkat pertanyaan tertulis kepada responden untuk dijawab dengan jenis kuesioner. Kuesioner dibagikan kepada responden yaitu karyawan perusahaan dan wawancara langsung dengan bagian yang berkepentinga di perusahaan tentang tingkat kebisingan dan pengaruh kebisingan yang dialami karyawan pada kawasan Compressor House Urea-1. 


\section{Hasil dan Pembahasan}

\subsection{Pengumpulan data}

Pengukuran tingkat kebisingan dilakukan di 30 titik di bagian Operasi-1 pengukuran dimulai dengan penandaan titik pengukuran di lokasi penelitian kemudian dilanjutkan pengukuran tingkat kebisingandengan menggunakan Sound Level Master (SLM) selama 5 hari dengan selama jam kerja dengan fraksi waktu dari pukul 8.00-21.00 pengukuran di lakukan di bagian operasi-1 yaitu di kawasan Compressor House Urea, GE House, Control Room Utility dan Gudang. Hasil pengukuran tingkat kebisingan .

Layout pengukuran dapat dilihat pada Gambar 1.

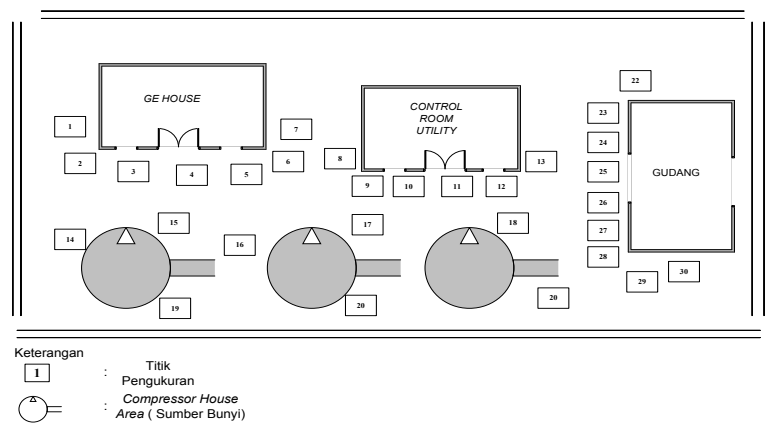

Gambar 1. Layout Pengukuran Kebisingan

\subsection{Pengolahan Data}

Pengolahan Data Tingkat Kebisingan di Bagian Operasi-1.

Berdasarkan peraturan tentang metode perhitungan kebisingan KEP48/MENLH/11/1996 bahwa tingkat kebisingan ekuivalen (Leq) dihitung dengan menggunakan formula:

$L e q=$

$10 \log \left\{f_{1} 10^{0.1 L_{1}}+\right.$ $\left.f_{2} 10^{0.1 L_{2}}+\ldots \ldots f_{n} 10^{0.1 L_{n}}\right\}$

$L_{n}=$ Tingkat Kebisingan ke- $n(n=1,2,3, \ldots, 30)$ Maka,

$$
\begin{gathered}
\text { Leq }=10 \log \left\{\frac{1}{30} 10^{0.1 \times 85,8}+\frac{1}{30} 10^{0.1 \times 85}+\frac{1}{30} 10^{0.1 \times 86}\right. \\
\left.+\frac{1}{30} 10^{0.1 \times 85}+\frac{1}{30} 10^{0.1 \times 83,00}\right\} \\
\text { Leq }=88,68 \mathrm{dBA}
\end{gathered}
$$

a. Tingkat Kebisingan Ekuivalen Total dengan menggunakan formula:

$$
\begin{aligned}
& \text { Leq } \\
& =10 \log \left\{f_{1} 10^{0.1 L_{1}}\right. \\
& \left.+f_{2} 10^{0.1 L_{2}}+\ldots \ldots \ldots f_{n} 10^{0.1 L_{n}}\right\}
\end{aligned}
$$

$f=$ fraksi waktu dengan pengukuran 5 hari (yaitu $=1 / 5$ )

$L_{n}=$ Tingkat Kebisingan ke-n

$$
(n=1,2,3,4,5)
$$

Maka,

Leq $=10 \log \left\{\frac{1}{5} 10^{0.1 \times 85.8}+\frac{1}{5} 10^{0.1 \times 85,6}+\right.$

$\left.\frac{1}{5} 10^{0.1 \times 85,5}+\frac{1}{5} 10^{0.1} \times 85,5+\frac{1}{5} 10^{0.1 \times 85,5}\right\}=$

85, 68Dba

b. Tingkat kebisingan siang

$$
\begin{aligned}
& \text { Leq } \\
& =10 \log \left\{f_{1} 10^{0.1 L_{1}}\right. \\
& \left.+f_{2} 10^{0.1 L_{2}}+\ldots \ldots \ldots f_{n} 10^{0.1 L_{n}}\right\}
\end{aligned}
$$

Maka,Leq $=$

$$
\begin{gathered}
10 \log \left\{\begin{array}{c}
\frac{3}{16} 10^{0.1 \times 83,68}+\frac{2}{16} 10^{0.1 \times 85,61} \\
+\frac{2}{16} 10^{0.1 \times 86,18} \\
+\frac{4}{16} 10^{0.1 \times 85,75}+\frac{4}{16} 10^{0.1 \times 86,02} \\
+\frac{1}{16} 10^{0.1 \times 86,26}
\end{array}\right\} \\
\operatorname{Leq}_{(\text {Siang) }}=\mathbf{8 5}, \mathbf{8 8} \text { Dba } \\
\text { Total tingkat kebisingan siang }
\end{gathered}
$$
hari dapat dilihat pada gambar 2 .

Tingkat Kebisingan Siang Hari

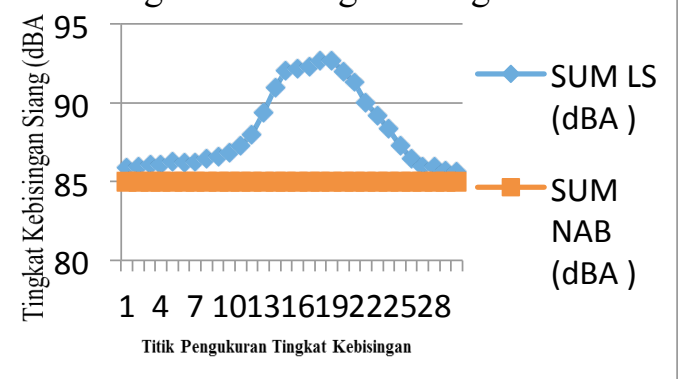

Industrial Engineering Journal Vol.8 No.1 (2019) 22-29 
Ergonomic and Work Design

Gambar 2. Total Tingkat Kebisingan Siang Hari

Adapun Uji Regresi Sederhana dapat dilihat pada tabel 3 dibawah ini

Tabel 3 Uji Regresi Sederhana variabel Entered/Removed

\begin{tabular}{|c|c|c|c|c|}
\hline \multicolumn{2}{|l|}{ Model } & $\begin{array}{l}\text { Variables } \\
\text { Entered }\end{array}$ & $\begin{array}{l}\text { Variables } \\
\text { Removed }\end{array}$ & $\begin{array}{l}\text { Meth } \\
\text { od }\end{array}$ \\
\hline \multicolumn{2}{|l|}{1} & Kebisingan & & Enter \\
\hline \multicolumn{5}{|c|}{ a. All requested variables entered. } \\
\hline \multicolumn{3}{|c|}{ b. $\begin{array}{l}\text { Dependent Variable: } \\
\text { pengaruh }\end{array}$} & c. & \\
\hline \multicolumn{5}{|c|}{ Model Summary } \\
\hline Model & $R$ & $\begin{array}{l}\mathrm{R} \\
\text { Square }\end{array}$ & $\begin{array}{l}\text { Adjusted } \\
\text { R Square }\end{array}$ & $\begin{array}{l}\text { Std Error } \\
\text { Of The } \\
\text { Estimate }\end{array}$ \\
\hline 1 & .593 & .352 & .329 & 9.15158 \\
\hline
\end{tabular}

c. Adapun Uji Korelasi Sederhana dapat dilihat pada tabel 4 dibawah ini Tabel 4 Uji Korelasi Sederhana

\begin{tabular}{llcc}
\multicolumn{4}{c}{ Correlations } \\
\hline \multicolumn{3}{c}{ Kebisingan } & Pengaruh \\
\hline Kebisingan & Pearson & 1 & $.693^{* *}$ \\
& Correlation \\
& Sig. (2-tailed) & & .001 \\
& $\mathrm{~N}$ & 30 & 30 \\
Pengaruh & Pearson & $.693^{* *}$ & 1 \\
& Correlation \\
& Sig. (2-tailed) & .001 & \\
$\mathrm{~N}$ & 30 & 30 \\
\hline
\end{tabular}

\begin{tabular}{|c|c|c|c|c|c|c|}
\hline \multicolumn{7}{|c|}{ ANOVA $^{b}$} \\
\hline \multicolumn{2}{|c|}{ Model } & $\begin{array}{l}\text { Sum of } \\
\text { Squares }\end{array}$ & Df & $\begin{array}{l}\text { Mean } \\
\text { Square }\end{array}$ & $\mathrm{F}$ & Sig. \\
\hline \multirow[t]{3}{*}{1} & $\begin{array}{l}\text { Regressi } \\
\text { on }\end{array}$ & 1273.126 & & 1273.126 & $\begin{array}{r}15.20 \\
1\end{array}$ & $.001^{\mathrm{a}}$ \\
\hline & Residual & 2345.041 & 28 & 83.751 & & \\
\hline & Total & 3618.167 & 29 & & & \\
\hline \multicolumn{7}{|c|}{$\begin{array}{l}\text { a. Predictors: (Constant), } \\
\text { kebisingan }\end{array}$} \\
\hline \multicolumn{3}{|c|}{$\begin{array}{l}\text { b. Dependent Variable: } \\
\text { pengaruh }\end{array}$} & & & & \\
\hline
\end{tabular}

Copyright (02019 Department of Industrial Engineering. All rights reserved.

\begin{tabular}{llcc}
\multicolumn{3}{c}{ Correlations } \\
\hline \multicolumn{3}{c}{ Kebisingan } & Pengaruh \\
\hline Kebisingan & $\begin{array}{l}\text { Pearson } \\
\text { Correlation }\end{array}$ & 1 & $.693^{* *}$ \\
& Sig. (2-tailed) & .001 \\
& $\mathrm{~N}$ & 30 & 30 \\
Pengaruh & Pearson & $.693^{* *}$ & 1 \\
& Correlation \\
& Sig. (2-tailed) & .001 & \\
& $\mathrm{~N}$ & 30 & 30 \\
\hline **. Correlation is significant at the 0.01 level (2- \\
tailed).
\end{tabular}

\subsection{Pembahasan}

Berdasarkan pengolahan data yang telah di lakukan maka tingkat kebisingan ekuivalen total di bagian operasi-1 khususnya dikawasan Compressor House Urea, Ge House, Control room utility area gudangsecara keseluruhan berada di atas Nilai Ambang Batas (NAB) yang ditetapkan oleh pemerintah Kep-51/MEN/1999 yaitu Untuk tingkat kebisingan siang hari berdasarkan pengumpulan dan pengolahan data yang telah dilakukan, tingkat kebisingan yang terendah berada pada titik pengukuran ke 30 sebesar 85,63 dan tingkat kebisingan tertinggi berada pada titik pengukuran 19 sebesar 92,67 Db. Selisih tingkat kebisingan yang akan direduksi sebesar 7,69 Db. Kebisingan di bagian operasi-1 ini ditimbulkan oleh mesin-mesin compressor yang beroperasi setiap harinya sehingga suara yang ditimbulkan mesin compressor tersebut merambat ke lingkungan sekitarnya seperti area gudang, GE house, dan Control Room Utility.Maka untuk tingkat kebisinganyang melebihi NAB tersebut pastinya akan membawa dampak bagi tenaga kerja yang setiap harinya yang melakukan aktivitas di area yang terpapar kebisingan tersebut.

Dari hasil pengukuran kelelahan tenaga kerja di bagian operasi-1 maka dapat diketahui bahwa dari populasi 30 tenaga kerja pada area ini $60 \%$ mengalami kelelahan berat,23\% mengalami kelelahan Industrial Engineering Journal Vol.8 No.1 (2019) 22-29 
sedang dan $17 \%$ mengalami kelelahan berat. Hal ini menunjukkan bahwasebagian besar tenaga kerja mengalami kelelahan sedang dan kelelahan berat. Dari menggunakan analisis regresi linear sederhana. Hasil analisis regresi linear sederhana menunjukan persamaan sebagai berikut:

$Y^{\prime}=a+b X$

$Y=-181.763+2.502$

Koefisien (a) sebesar -1.81 .763$ artinya jika tingkat kebisingan (X) nilainya adalah 0 maka kelelahan (Y) nilainya negatif yaitu sebesar -1.81 .763 . koefisien $b$ tingkat kebisingan (X) sebesar 2.502 artinya jika tingkat kebisingan mengalami kenaikan sebesar 1 dB maka kelelahan (Y) akan mengalami peningkatan sebesar 2.502 . Koefisien (b) bernilai positif artinya terjadi hubungan positif antara tingkat kebisingan dengan kelelahan, sehingga semakin tinggi kebisingan maka semakin meningkat pula tingkat kelelahan. Dari hasil perhitungan korelasi didapatkan $r=0,693$ bernilai positif, artinya terdapat hubungan atau korelasi yang kuat antara kebisingan dengan kelelahan kerja. Semakin tinggi tingkat kebisingan maka semakin tinggi tingkat kelelahan kerja pada karyawan.

\section{Kesimpulan dan Saran}

\subsection{Kesimpulan}

Adapun kesimpulan diperoleh dari hasil penelitian adalah sebagai berikut :

1. Tingkat kebisingan pada bagian operasi1 khususnya pada kawasan Compressor House Urea berdasarkan dari 30 titik pengukuran diperoleh kebisingan tertinggi sebesar 92,69 dba, hal ini ini dapat dikatakan sudah melewati ambang batas yang sudah ditentukan oleh Kep. 48/ MENLH/ 11/ 1996 tentang kebisingan pada kawasan industri

2. Berdasarkan hasil pengolahan data dan analisis korelasi sederhana yang telah dilakukan sebelumnya maka bahwa tingkat kebisingan berpengaruh terhadap kelelahan sebesar $r=0,693$ yang berarti hubungan kebisingan dan kelelahan kuat dan semakin semakin tinggi tingkat kebisingan maka semakin meningkat kelelahan

3. Pengaruh kebisingan dilihat dari tingkat kelelahan responden sebagian besar mengalami kelelahan sedang dan kelelahan berat. Bahwa tingkat kebisingan dapat mengganggu kesehatan tenaga kerja yang bekerja pada bagian operasi-1 terutama di area Compressor House Urea

\subsection{Saran}

Adapun saran yang ingin dilakukan perusahaan adalah sebagai berikut:

1. Pada bagian operasi-1 khususnya di kawasan Compressor House Urea pada saat melakukan aktivitas diwajibkan memakai (APD).

2. Dilakukan penanaman pohon di lingkungan yang terpapar kebisingan dari mesin Compressor House Urea.

3. Dilakukan pemeriksaan kesehatan berkala khususnya audiometri terhadap seluruh tenaga kerja di bagian yang tingkat kebisingannya melebihi NAB untuk memantau kondisi ambang dengar tenaga kerja.

\section{DAFTAR PUSTAKA}

[1] Sukmono, Daniel haris., 2010. Pengaruh Kebisingan Terhadap Tingkat Kelelahan Kerja Di Penggilingan Padi Desa Griyan Keluran Baturan kecamatan Colomadu Kab.Karangnyar, Jurnal Fakultas Kedokteran Universitas Sebelas Maret, Surakarta.

Industrial Engineering Journal Vol.8 No.1 (2019) 22-29 
Ergonomic and Work Design

[2] Kep.Men.LH No. 48, 1996. Baku

Tingkat Kebisingan, Menteri

Lingkungan Hidup, Indonesia.

[3] Marji. (2009) Dampak Kebisingan Terhadap Pekerja Pabrik Pada Berbagai Latar Belakang Tingkat Pendidikan.

[4] Buchari. 2007. Kebisingan Industri dan Hearing Conservation Program. USU Repository: Universitas Sumatera Utara.

[5] Dwi P. Sasongko, dkk 2000. Kebisingan Lingkungan. Semarang. UNDIP

[6] Halliday, Resnick, dan Walker. 2010. Fisika Dasar Edisi ke 7. Jakarta: ERLANGGA. 